\title{
Floristic diversity and demographic structure of the Sidi R'Ghies forest, north-eastern of Algeria
}

\author{
MALIKA RACHED-KANOUNI ${ }^{1}$, KARIMA KARA $^{2}$, HICHEM KHAMMAR $^{1, \boldsymbol{v}}$, LABED ABABSA $^{1}$ \\ ${ }^{1}$ Department of Natural and Life Sciences, Faculty of Exact Sciences and Natural and Life Sciences, Larbi Ben M'Hidi Oum El Bouaghi University. \\ Oum El Bouaghi 04000, Algeria. "email: khammar.eco.env@ gmail.com \\ ${ }^{2}$ Department of Biology and Plant Ecology, Faculty of Natural and Life Sciences, Université des Frères Mentouri Constantine 1. BP, 325 Route Ain el \\ Bey, 25017 Constantine, Algeria
}

Manuscript received: 22 November 2019. Revision accepted: 4 February 2020.

\begin{abstract}
Rached-Kanouni M, Kara K, Khammar H, Ababsa L. 2020. Floristic diversity and demographic structure of the Sidi R'Ghies forest, north-eastern of Algeria. Biodiversitas 21: 875-881. In Algeria, the degradation of the ecosystems induces a loss of biodiversity and an increase in the adverse effects of climate change and anthropogenic actions, especially at the level of the ecosystems of semi-arid zones. This study aims to determine the floristic composition and demographic structures of different stands within the Sidi R'Ghies forest, north-east of Algeria. Data were collected using floristic surveys, diameter measurements at $1.30 \mathrm{~m}$ and total height for trees in four plots with size for each plot of $1000 \mathrm{~m}^{2}$. The diversity indices have been calculated on the basis of specific frequencies. The analysis revealed a low floristic richness with 6 woody species belonging to 5 families with the most dominant are the Cupressaceae and Fagaceae (29\%). The low density of woody trees (97.78 individuals/ha) was found in Plot 1 and the high density of 205.56 individuals/ha was found in Plot 4. The diametric structure adjusts to the Weibull distribution and shows a predominance of young individuals. The distribution of trees in height classes shows a single distribution with an asymmetric curve. This positive distribution reveals a predominance of individuals with a height between 2 and $8 \mathrm{~m}$ (sapling to mature stage). This work, which provides an overview of the state of the floristic diversity of the Sidi R'Ghies forest, allows taking appropriate measures to safeguard our plant resources.
\end{abstract}

Keywords: Demographic structure, floristic composition, Sidi R'Ghies, spatial structure, Weibull distribution

\section{INTRODUCTION}

Forests play an important role in building resilience to climate change. Forest trees do great good for the environment, for example by improving the quantity and quality of available water, reducing soil erosion and creating microclimates that maintain or even optimize agricultural productivity. Sustainable forest management can also strengthen the resilience of local societies by expanding the range of income sources and products available, while building the capacity of local and national institutions (FAO 2016).

Despite these multiple functions, the management of natural forests, particularly in arid and semi-arid areas in Algeria, is confronted with a lack of data to understand how these ecosystems function in terms of floristic composition, demographic structure, and regeneration. Consequently, developing sustainable management strategies and approaches based on sound science remains very difficult (Godoy 1992). However, data on the structural characteristics and dynamics of plant species are unfortunately not documented. The study of the structure of a forest formation provides the basis for its silviculture, guides forest management, assesses the state of ecosystem degradation, helps to understand the past management history of stands and forest dynamics (Merino et al. 2007).

The spatial structure of an ecosystem, i.e. the way in which its individuals are organized in space, often plays an essential role in its functioning (Delvaux 1981; Barot et al.
1999; Pascal 2003). It refers to both the vertical and horizontal use of space by ecosystem components (Svensson and Jeglum 2001). The structure of a forest species population is generally defined by the diametric distribution of the species (Herrero-Jáuregui et al. 2012). They reflect the dynamic state of the stand as a whole, the physiological characteristics of the species, the particular situations and the ecological preferences of the species (Denslow 1995; Collinet 1997; Pascal 2003; Webster et al. 2005; Tessi et al. 2012; Pastorella and Paletto 2013).

Knowledge of the structure of populations seems necessary to better understand the level of threat and propose sustainable management strategies. Thiombiano et al. (2016) rightly point out that forest inventories are an essential part of sustainable wood resource management policies.

The mountain of Sidi R'Ghies is characterized by a special vegetation cover different from other areas of the region of Oum El Bouaghi. This is due to the importance of its surface estimated at 3106 ha and to the altitude which varies between $1030 \mathrm{~m}$ and $1635 \mathrm{~m}$ like the mountainous reliefs which characterize the chain of Aurès. It appears through these characteristics that the amount of rain that falls on this mountainous area is quite significant despite the situation of the region of Oum El Bouaghi in the semiarid bioclimatic stage with acute climatic variations. Having an influence on the nature and composition of soils and consequently on the plant cover and its development, this has resulted in the diversity of plant species. The plant 
assemblages that exist today are not the product of the succession of different phases that are subject to change over time, but their essential reason is due to human intervention (Mosbah 2007).

The forest of djebel Sidi R'Ghies is formed of a natural unit characterized by a vegetable cover, made up essentially of autochthonous species, one finds there the holm oak (Quercus ilex), the juniper of Phoenicia (Juniperus phoenicea), the oxycedre (Juniperus oxycedrus), the Atlas pistachio tree (Pistacia atlantica) and the wild olive tree (Olea europaea), its artificial set is represented by reforestation with the main species the Aleppo pine (Pinus halpensis) accompanied by Cypressus sempervirens, Acacia cyanophilla and Eucalyptus camadulensis.

In the Sidi R'Ghies forest, studies are almost absent to understand their ecological functioning and assess their diversity. It is to fill such a scientific gap that this study was carried out in order to characterize the composition, diversity, and structure of the plant groups in this forest. It constitutes a basic study to understand the functioning of the Sidi R'Ghies forest before any sustainable management action.

\section{MATERIALS AND METHODS}

\section{Study area and period}

The forest of Sidi R'Ghies is located in the northern part of the city of Oum El Bouaghi, between the lines of latitude $53^{\circ} 52^{\prime} 5 \mathrm{~N}$ in the south and $35^{\circ} 57^{\prime} \mathrm{N}$ in the north and between the lines of longitude $07^{\circ} 06^{\prime} \mathrm{E}$ in the west and $07^{\circ} 10^{\prime} \mathrm{E}$ in the east of the Greenwich meridian (Figure 1). Its altitude is about $1635 \mathrm{~m}$ asl. The Sidi R'Ghies forest has an estimated extent of 3106 ha with perimeter length of $28.66 \mathrm{~km}$ (Mosbah 2007). The climate is semi-arid with cool winter, with an average annual rainfall of $378 \mathrm{~mm}$ and an average annual temperature of $25^{\circ} \mathrm{C}$. The study is conducted during the period March-June 2019.

\section{Data collection procedure}

Vegetation data were collected in rectangular plots of $20 \mathrm{~m} \times 50 \mathrm{~m}\left(1000 \mathrm{~m}^{2}\right)$ (Figure 2). Within each plot, the diameter at breast height $(\mathrm{DBH}$, i.e. $1.30 \mathrm{~m}$ from the ground) was measured for all species including $\mathrm{DBH} \geq$ $2 \mathrm{~cm}$. The total height was measured using Bloom Lies on individuals of characteristic and valuable forest species by diameter class and plot. This positioning made it possible to highlight the spatial distribution of trees in the study area. The densities of the trees on the upper floor were obtained by simple counting.

\section{Data analysis}

Data analysis focused on floristic and structural parameters. The evaluation of the floristic parameters was done by calculating the following diversity indices.

Shannon's diversity index (H') (1949) taken up by Grall and Hily (2003). It is used to assess the diversity of species within a biotope and is calculated by the formula, $H^{\prime}=-\Sigma$ $(\mathrm{Ni} / \mathrm{N}) \log _{2}(\mathrm{Ni} / \mathrm{N})$ in which $\mathrm{Ni}$ is the number of species of rank $\mathrm{i}$ and $\mathrm{N}$ is the total number of all species. This index varies from 0 when only one species is present, to $\log \mathrm{S}$ when all species have the same abundance (Dajoz 2008).
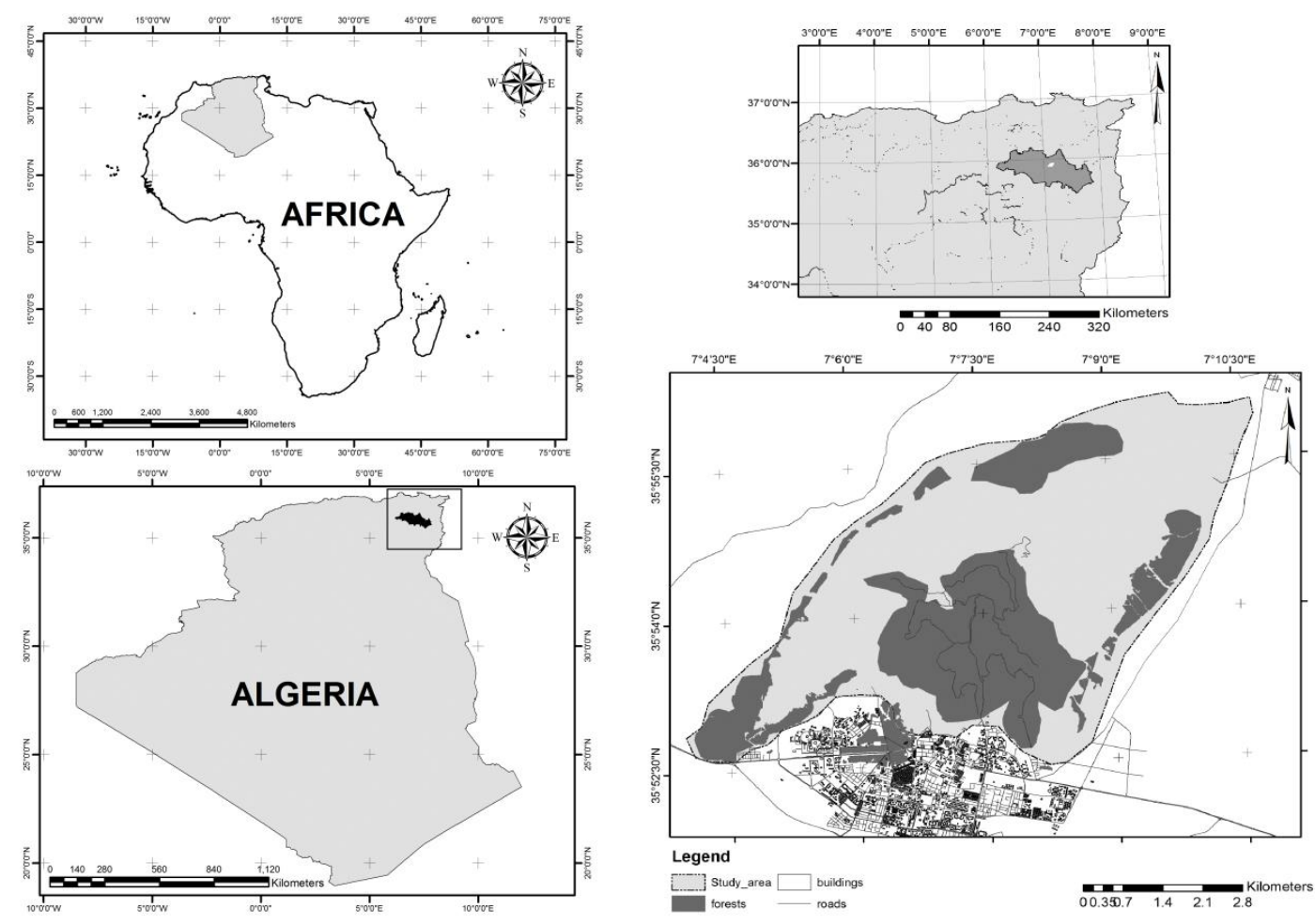

Figure 1. Geographical location of the study area (Rebbah 2019) 


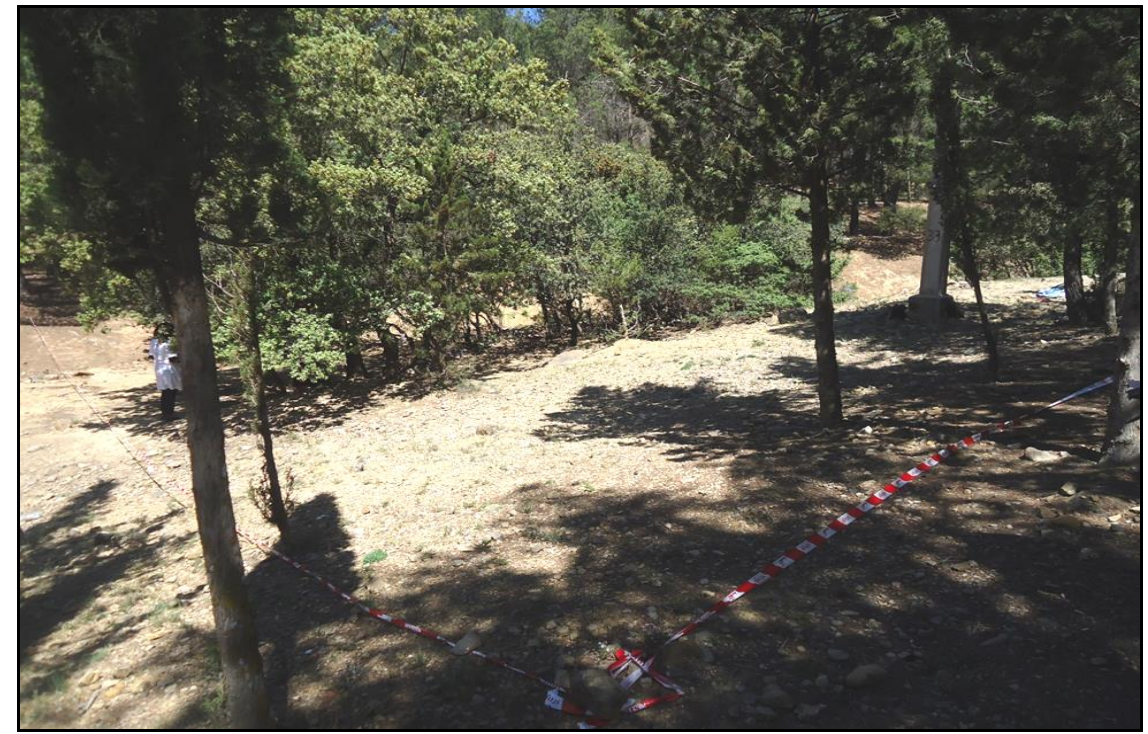

Figure 2. Plot of Quercus ilex

Simpson's index gives the probability that two randomly selected individuals in a population belong to the same species. The formula used to calculate is $\mathrm{D}=1-\Sigma$ $(\mathrm{Ni} / \mathrm{N})^{2}$. It is a diversity index that varies between 0 and 1 . In order to obtain more intuitive values, we have preferred to apply the Simpson's diversity index represented by $1-\mathrm{D}$, where the maximum diversity is represented by the value 1 and the minimum diversity is represented by the value 0 (Schlaepfer and Bütler 2002). It gives more weight to abundant species than to rare species. The addition of rare species to a sample does not change abruptly the value of the diversity index study the Simpson's diversity index represented by $1-\mathrm{D}$, the maximum of diversity being represented by the value 1 , and the minimum diversity being 0 .

Pielou's equitability index provides information on how individuals are distributed within species. Equireparition is the ratio between the actual diversity and the maximum diversity corresponding to equal numbers of individuals (Pielou 1969; Routledge 1979; Simboura and Zenetos 2002). Its formula is as follows, $E=H^{\prime} / \log _{2}$ (S). Equitability tends towards 0 when almost all individuals belong to the same species and is equal to 1 when all species have the same abundance (Dajoz 2000).

Species richness $S$ is the simplest measure of biodiversity and is simply a count of the number of different species in a given area (Margurran 2004). This measure is strongly dependent on sampling size and effort.

The Margalef diversity index can easily be calculated in a spreadsheet using formula as follows, $D_{M g}=(S-1) / \ln$ $N$. Where $\mathrm{S}$ is the number of species, and $\mathrm{N}$ is the total number of individuals in the sample (Gamito 2010; Mamgambou et al. 2013b).

Importance Value Index (IVI): IVI is an index quantitative identification of the species ecologically important in a community (Adomou et al. 2009). It varies from 0 (absence dominance) to 300 (mono-dominance) This index is expressed according to the following formula, IVI $=$ Relative density + Relative dominance + Relative frequency (for the species). This index makes it possible to highlight the ecological importance of species and families (Kabore et al. 2013). The IVI provides information on the place that each taxonomic group occupies in relation to all species within a plant community. Relative values density, dominance, frequency, and diversity were calculated for species and families according to Cottam and Curtis (1956) and Mori et al. (1983).

An analysis of variance was performed to compare dendrometric parameters: density $(\mathrm{N})$, mean diameter $(\mathrm{Dg})$, mean Lorey height (HL) and basal area $(\mathrm{G})$ of stands in the different sampled plots. The average Lorey's height (HL), or average tree height, is the average of the heights of individuals weighted by their basal area (Philip 2002).

The mean values of the various measured dendrometric parameters (height and diameter) and other calculated parameters (density, basal area, Lorey height) were used for a principal component analysis (PCA) to characterize and discriminate the plots of the Sidi R'Ghies forest.

\section{Demographic structure}

An adjustment test to the Weibull theoretical distribution (Hamidou et al. 2017) was performed using Minitab 18 software. The Weibull theoretical distribution with three parameters (position a, scale or size b and shape c) was used to characterize stand structure, due to its flexibility of use and the large variability in distribution forms it produces. Parameter (a) corresponds to the threshold value, i.e. the smallest diameter value (respectively height value) used for the constitution of the histograms. Parameter (b) is related to the central value of the distribution of the diameter and height classes. Finally, parameter (c) is related to the observed structure and depending on its value, leads the Weibull distribution to take several forms. Its probability density function $\mathrm{f}(\mathrm{x})$ is in the following form (Kotz and Johnson 1970):

$$
f(x)=\frac{c}{b}(x-a / b)^{c-1} \quad \exp \left[-\left(\frac{x-a}{b}\right)^{c}\right]
$$


With $\mathrm{x}$ is the diameter $(\mathrm{cm})$, circumference $(\mathrm{cm})$ or height $(\mathrm{m})$ of the trees, $\mathrm{f}(\mathrm{x})$ its probability density value generated from the centers of the diameter or height classes and the parameters $a, b$ and $c$. To verify the significance of the adjustment according to the null hypothesis of equality between the observed frequencies of diameter class (respectively height class) considered and the theoretical frequency expected according to the Weibull function (Agresti 2010), a log-linear analysis, an iterative method of analyzing the variance of the logarithm of class densities, was performed.

\section{RESULTS AND DISCUSSION}

\section{Results}

The results of this study provide important information on the variation in plant diversity and spatial structure of the Sidi R'Ghies forest. The floristic inventory of woody vegetation within the plots of this forest has made it possible to count 6 species divided into 5 families. The results of this study showed that the flora of the vegetation in this area is mainly dominated by Cupressaceae and Fagaceae (29\% each), followed by Pinaceae (21\%) and Oleaceae (14\%), while Anacardiaceae is the least frequent family $(7 \%)$.

Shannon's diversity indices determined through species recovery show that the groups studied are poorly diversified. It varies from 0.58 for P4 to 0.97 for P1 (Table 1). Simpson's Diversity Index values range from 0.38 to 0.61 respectively for plots 2 and 4 . The results of the floristic composition showed that this forest is lower in tree species than other biotopes in Algeria. The floristic diversity in this environment is likely linked to the climate, poor soil and anthropic actions. The equitability of Pielou (E) reaches its maximum of 0.86 for Plot 4 and its minimum of 0.45 for Plot 2 (Table 1). Mixing coefficients vary from 0.05 to 0.11 for the four plots.

For dendrometric characteristics, the average density is 131.74 individuals per hectare. Plot 4 has the highest number of stems per hectare at 205.56 feet, while Plot 1 has a lower density at 97.78 feet per hectare (Table 2). Plot 2 has the largest average Lorey diameter and height values, $16.88 \mathrm{~cm}$ and $5.89 \mathrm{~m}$ respectively. The lowest basal area value $\left(0.46 \mathrm{~m}^{2} \mathrm{ha}^{-1}\right)$, while the highest value was observed at Plot $1\left(10.3 \mathrm{~m}^{2} \mathrm{ha}^{-1}\right)$. The two species Pinus halepensis and Quercus ilex, with an average density of 159 and 283 feet per hectare respectively, are the most abundant.

The principal component analysis (PCA) was applied to the matrix obtained from 10 quantitative variables measured on four plots in this study. Calculations made with the Minitab software give the characteristics of the three main axes. The first two axes explain $97.13 \%$ of the information provided by the four plots. Three groups of variables were highlighted by the correlation circle of all plots in the factorial plane of axes 1 and 2 (Figure 3). The
Group (G1) in the positive axis is formed by the parameters whose correlation is important. These are the variables of density, basal area, Pielou index and Simpson index with Plots 3 and 4. The second group (G2) is represented by the parameters of mean diameter, Lorey's height, Hmax index, Hill and Margalef index which are negatively correlated with the first group. The second axis is represented by only one parameter (i.e. Shannon index) which is positively correlated with Plot 1.

The importance value index (IVI) gives the level of importance of a species within the community (P1, P2, P3, and P4) in the Sidi R'Ghies forest. The species with the highest IVI are Quercus ilex (127.66\%) and Pinus halepensis (97.89). These species mark the physiognomy of the vegetation of this forest. The species with the lowest value is Pistacia atlantica (7.92\%) (Table 3 ).

Analysis of the vertical structure of the woody stand shows that the flora of the Sidi R'Ghies forest is dominated by young individuals with a height between 2 and $8 \mathrm{~m}$. Individuals over $8 \mathrm{~m}$ and under $14 \mathrm{~m}$ in height are few in number and those over $14 \mathrm{~m}$ in height are almost absent in this area. The distribution of trees in classes of total height with an amplitude of $3 \mathrm{~m}$ shows a single distribution in the four plots whose appearance is similar to an asymmetric curve on the right. This positive distribution reveals a predominance of individuals with a height between 2 and 8 $\mathrm{m}$ with a density of 823 individuals/ha (saplings stage) (Lantovololona 2010). The study plots are characterized by a shape parameter of the theoretical Weibull distribution between 1.633 and $3.181(1<\mathrm{c}<3.6)$; characteristic of populations with high regeneration potential but with survival problems during the transition between development stages. Log-linear analysis shows that all observed height structures adjust with the Weibull distribution (Figure 3).

Table 1. Diversity indices of vegetation community of the Sidi R'Ghies, Algeria

\begin{tabular}{lcccccc}
\hline Plots & H' & Hmax & E & 1-D & Hill & M \\
\hline P1 & 0.97 & 1.61 & 0.60 & 0.0 .44 & 0.90 & 1.06 \\
P2 & 0.73 & 1.61 & 0.45 & 0.370 .38 & 1.30 & 1.04 \\
P3 & 0.78 & 1.10 & 0.71 & 0.530 .55 & 0.86 & 0.55 \\
P4 & 0.58 & 0.69 & 0.86 & 0.620 .61 & 0.90 & 0.28 \\
\hline
\end{tabular}

Table 2. Dendrometric parameters

\begin{tabular}{lcccc}
\hline Parameters & P1 & P2 & P3 & P4 \\
\hline Average density $(\mathrm{N} / \mathrm{ha})$ & 97.78 & 127.78 & 144.44 & 205.56 \\
Average diameter $(\mathrm{cm})$ & 12.35 & 16.88 & 14.45 & 11.85 \\
Average basal area $\left(\mathrm{m}^{2} / \mathrm{ha}\right.$ & 1.10 & 0.84 & 0.67 & 0.46 \\
Average height of Lorey $(\mathrm{m})$ & 5.31 & 5.89 & 5.28 & 4.93 \\
\hline
\end{tabular}




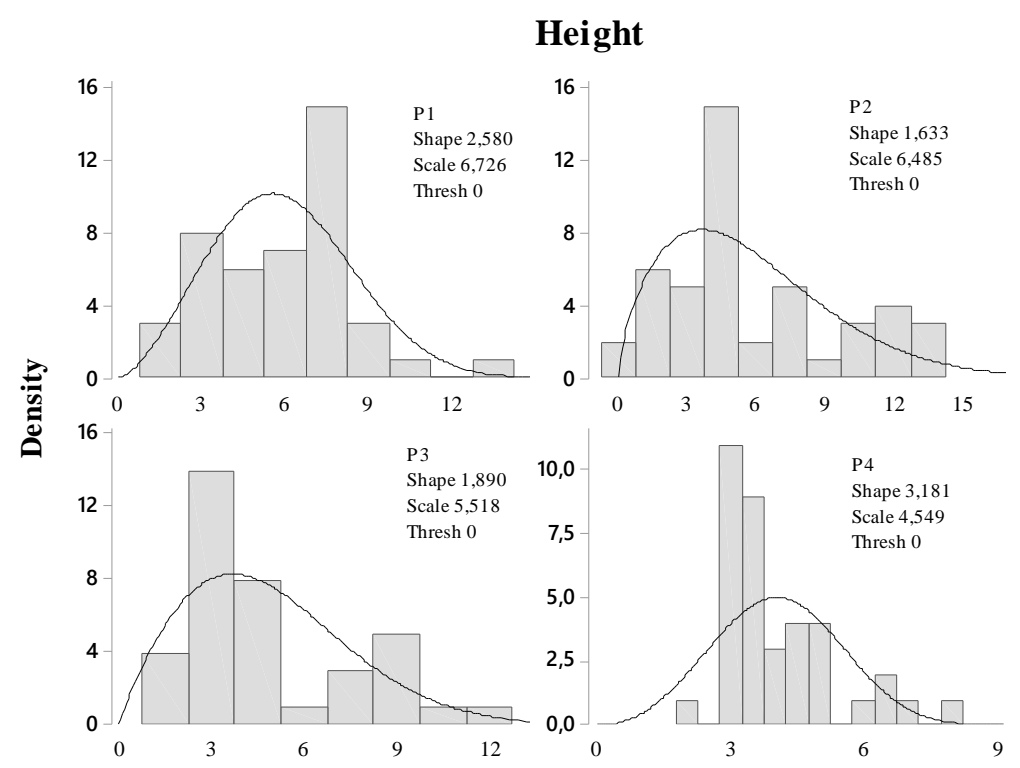

Figure 4. Height structure of plant groups in the four plots

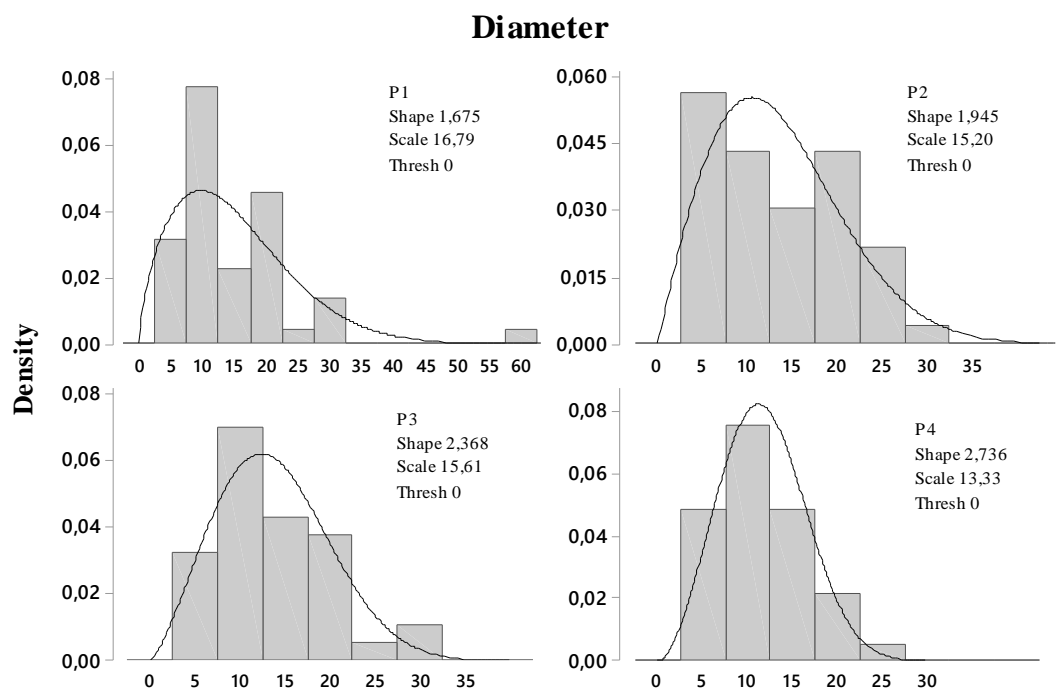

Figure 5. Diameter structure of plant groups in the four plots

The diameter class distributions of the stands for the four plots (P1, P2, P3, and P4) are presented in Figure 4, which shows that the observed distributions of the three groups adjust with their theoretical Weibull distributions ( $\mathrm{P}$ $>0.05)$. The values of the shape parameter $\mathrm{c}$ are between 1 and 3.6 for the three groups, reflecting a positive asymmetric distribution, characterized by a predominance of young and small diameter individuals. The number of large diameter individuals is very small and as the diameter increases (Figure 5), the number of individuals decreases or even becomes completely absent. Centered bell distribution, characterized by larger numbers in the middle classes of diameter compared to the small and large diameter classes. This type of distribution is found in the populations of plots 3 and 4 (Group 1).
The bell distribution offset to the left, characteristic of a decreasing distribution of individuals from small diameter classes to large diameter classes. This is the case for the populations of plots 1 and 2 (Group 2). The strong presence of young individuals can be explained by germinations made by strains.

\section{Discussion}

Interest in biodiversity has recently increased in response to ecosystem damage caused by human activities (Niggemann et al. 2009). Studies to explain the effect of environmental factors and human disturbances on plant biodiversity in the Sidi R'Ghies forest are virtually absent. Environmental factors play a significant role in the discrimination of plant groups (Ababou et al. 2009). The 
significant human effect on plant dispersion, the distribution of plant communities and the isolation or fragmentation of plant groups have been highlighted by previous studies (Ababou et al. 2009; Liu et al. 2009).

The floral richness of the Sidi R'Ghies forest is lower than that obtained by some works carried out in the Constantine or Skikda forests located in the north-east of Algeria (Hadef et al. 2014; Rached-Kanouni et al. 2015). This difference would be due to unfavorable climatic conditions, soil structure, and the absence of silvicultural work. This low diversity is mainly due to anthropogenic factors, as the forest is pre-urban, climatic conditions are characterized by a long period of drought during the summer period and the soil is degraded. Human factors strongly disrupt ecosystem functioning, resulting in changes in plant composition and structure (Abdullah and Nakagoshi 2007).

The values of the diversity indices are insignificant and indicate low floristic diversity (Table 2). The Shannon index is often accompanied by the Pielou equitability index. The equity index measures the distribution of individuals within species, regardless of specific wealth. Its value varies from 0 (dominance of one of the species) to 1 (even distribution of individuals in the species). These two indices remain dependent on sample size and habitat type. It is therefore difficult to make it a descriptor of the state of an environment unless threshold values for each habitat type and for a given sampled area are first determined, as proposed (Ramalanjoana 2013). Mixing coefficients vary from 0.05 to 0.11 for the four plots; these coefficients reflect the trend towards homogeneity of the different stands.

The distribution by diameter and height classes shows a low density of individuals of large diameter and height greater than $7 \mathrm{~m}$ respectively. The low density of species in the area is linked to the anthropogenic actions (e.g. fire, logging) and drought that has occurred and is occurring in this area in recent years. To these factors, we can also add the impact of overgrazing by animals, which can contribute to the disappearance of certain plant species from the environment. Analysis of the histograms of the diameter and height classes also shows that the vegetation of the Sidi R'Ghies forest is dominated by young individuals. Diameter class distribution is used to understand tree dynamics and can be used to assess the impact of anthropogenic pressure on tree populations (Cunningham 2001). At the scale of the forest complex, the distribution of individuals into diameter classes revealed a progressive decrease in the number of individuals as the diameter class increases. According to Whitmore (1990), the high densities of small diameter classes ensure the future of natural formation while the low densities of large tree classes are the result of natural selection and are in fact the seed companies that ensure sustainability of the stand. Such a distribution is typical of stable populations, which are likely to be renewed through natural regeneration (Mbayngone et al. 2008).

Potential regeneration is low. Human actions greatly reduce the chances of regeneration. According to Biaou (2009), repeated wildfires combined with grazing would have a more negative impact on tree regeneration (recruitment) than when each of these anthropogenic pressures is considered separately (Natta 2011a).

In conclusion, the study conducted in the Sidi R'Ghies forest contributed to a better knowledge of the floristic composition and structure of the woody stands in the different plots studied. It revealed that Fagaceae and Pinaceae are the dominant families. The assessment of species diversity using the Shannon, Simpson, Pielou, Hill and Margalef indices shows a certain relationship with environmental disturbances and adverse natural conditions. The study area is characterized by a predominantly small diameter stand of individuals, reflecting significant species regeneration. Large diameter individuals are almost absent in the different stands, so silvicultural analysis has provided knowledge on forest stands, their size, dynamism, state of development, demographics. In addition to anthropogenic pressure (fire, waste, grazing, etc.), climatic factors, therefore, contribute to the degradation of the character stands in this area. These assets argue in favor of strengthening the strategies for the sustainable development and management of the Sidi R'Ghies forest.

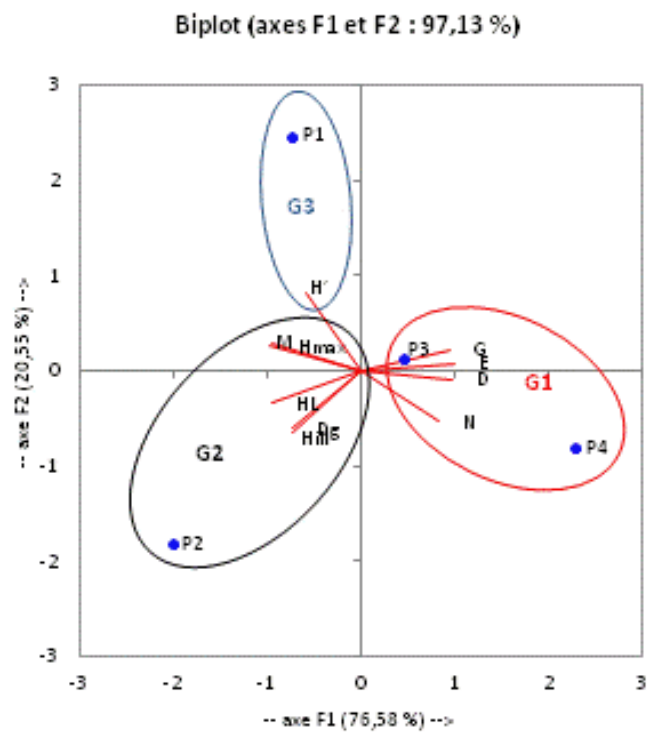

Figure 3. Graphical representation of plant groups by the CPA

Table 3. Importance Value Index (IVI) of species in the Sidi R'Ghies forest, Algeria

\begin{tabular}{lcccc}
\hline Species & Dr & Fr & Gr & IVI (\%) \\
\hline Pinus halepensis & 24.71 & 21.43 & 51.75 & 97.89 \\
Quercus ilex & 58.05 & 28.57 & 41.04 & 127.66 \\
Pistacia atlantica & 0.57 & 7.14 & 0.20 & 7.92 \\
Olea europaea & 1.72 & 14.29 & 2.26 & 18.27 \\
Juniperus oxycedrus & 9.20 & 21.43 & 1.96 & 32.59 \\
Cypressus sempervirens & 5.75 & 7.14 & 2.79 & 15.68 \\
Total & 100 & 100 & 100 & 300 \\
\hline
\end{tabular}




\section{REFERENCES}

Ababou A, Chouieb M, Khader M, Mederbal K, Bentayeb Z, Saidi D 2009. Analyse des associations végétales de la plaine salée du BasCheliff, Algérie. Acta Biol Par Curitiba 38 (1-2): 75-91.

Abdullah SA, Nakagoshi N. 2007. Forest fragmentation and its correlation to human land use change in the state of Selangor, peninsular Malaysia. For Ecol Manag 241: 39-48.

Adomou CA, Mama A, Missikpode R, Sinsin B. 2009. Cartographie et caractérisation floristique de la forêt marécageuse de Lokoli (Bénin) Int J Biol Chem Sci 3 (3): 492-503.

Agresti A. 2010. Analysis of Ordinal Categorical Data. 2nd ed. Wiley, New York, USA.

Barot S, Gignoux J, Menaut JC. 1999. Demography of a savanna palm tree: predictions from comprehensive spatial pattern analyses. Ecology 80 (6): 1987-2005.

Biaou HS. 2009. Tree recruitment in West African dry woodlands: The interactive effects of climate, soil, fire, and grazing. [Dissertation] Wageningen University, Wageningen, The Netherlands.

Collinet F. 1997. Essais de regroupements des principales espèces structurantes d'une forêt dense humide d'après l'analyse de leur répartition spatiale (Forêt de Paracou-Guyane). [French]

Cottam G, Curtis JT. 1956. The use of distance measures in phytosociological sampling. Ecology 37: 451-460.

Cunningham AB. 2001. Applied Ethnobotany. People Wild Plant Use and Conservation. People and Plants Conservation. Earthscan, London.

Dajoz R. 2000. Précis d'écologie. Dunod, Paris, France. [France]

Dajoz R. 2008. La biodiversité : l'avenir de la planète et de l'homme. Ellipses, Paris, France. [France]

FAO. 2016. The State of World Fisheries and Aquaculture 2016 Contributing to food security and nutrition for all. FAO, Rome.

Delvaux J. 1981. Différenciation sociale. J de Foresterie Suisse 132: 733749. [France]

Denslow JS. 1995. Disturbance and diversity in tropical rain-forests - the density effect. Ecol Appl 5: 962-968

Gamito S 2010. Caution is needed when applying Margalef diversity index. Ecol Indicat 10: 550-551.

Godoy R. 1992. Some organizing principles in the valuation of tropical forests. For Ecol Manag 50: 171-180.

Grall J, Hily C. 2003. Traitement des données stationnelles (faune). Fiche technique. http: //www.ifremer.fr/rebent/. [France]

Hadef A, Mouhli N, Rached-Kanouni M, Alatou D. 2014. Cartographic approach to regression of forest ecosystems in the area of Guerbes (Algeria). Intl J Manag Sci Business Res 3 (5): 43-50.

Hamidou A, Habou R, Abdoulaye D, Boubé M, Ali M, Ronald B. 2017. Structure démographique et répartition spatiale des populations de Sclerocarya birrea (A. Rich.) Hochst du secteur sahélien du Niger. Bois et forêts des tropiques, $\mathrm{n}^{\circ} 333$ (3) focus / population structure and spatial distribution of Sclerocarya birrea, 55-65

Herrero-Jáuregui C, García-Fernández C, Sist PL, Casado MA. 2012. Recruitment dynamics of two low-density neotropical multiple-use tree species. Plant Ecol 212 (9): 1501-1512.

Kabore E, Sambare O, Ouedraogo A, Thiombiano A. 2013. Diversité et structure des cordons ripicoles le long de la sirba (Nord-Est du Burkina Faso). Intl J Biol Chem 7 (5): 1929-1950.

Kotz S, Johnson NL. 1970. Distributions in Statistics: Continuous Univariate Distributions. John Wiley \& Sons, New York.

Lantovololona F. 2010. Inventaire floristique et caractérisation des usages des ressources végétales dans la zone d'extension de la réserve spéciale de Beza Mahafaly. [Mémoire de fin d'étude en vue de l'obtention de Diplôme d'ingénieur en sciences agronomiques] option eau et forêts, Université d'Antananarivo, école supérieure des sciences agronomiques, département des eaux et forêts. [France]

Liu B, Zhao W, Wen Z, Teng, J, Li X, 2009. Floristic characteristics and biodiversity patterns in the Baishuijiang River Basin, China. Environ Manag 44: 73-83.

Mamgambou M, Muhashy H, Janssen T, Diggelen R, Robbrecht E, Ntahobavuka H. 2013b. Diversité des Fougères et leurs alliées le long du gradient altitudinal au sein de l'écosystème forestier des montagnes du Parc National de Kahuzi- Biega (R.D. Congo).Int J Environ Stud 70 (2): 259-283. [France]

Margurran A. 2004. Measuring Biological Diversity. Blackwell Publishing Company, United Kingdom.

Mbayngone E, Thiombiano A, Hahn-Hadjali K, Guinko S. 2008. Structure des ligneux des formations végétales de la Réserve de Pama (Sud-Est du Burkina Faso, Afrique de l'Ouest). Flora et Vegetatio SudanoSambesica 11: 25-34. [France]

Merino A, Real C, Álvarez-González JG, Manuel A, Rodríguez-Guitián M A. 2007. Forest structure and C stocks in natural Fagus sylvatica forest in southern Europe: The effects of past management. For Ecol Manag 250: 206-214

Mori SA, Boom BM, De Carvalino AM, Dos Santos TS. 1983. Southern Bahian Moist Forest. Bot Rev 49: 155-232.

Mosbah B. 2007. Etude comparative de la dynamique de la flore lichénique corticole sur Quercus ilex L., et Pistacia atlantica Desf au niveau du Djebel Sidi R'ghies-Oum El Bouaghi-[Mémoire d'ingenieur]. Centre Universitaire Larbi Ben M'hidi Oum ElBouaghi, Algérie. [France]

Natta AK, Yédomonhan H, Zoumarou-Wallis N, Houndéhin J, Ewédjè EBK, Glèlè Kakaï RL. 2011a. Typologie et structure des populations naturelles de Pentadesma butyracea dans la zone soudano-guinéenne du Bénin. Annales des Sci Agronomiques $15: 217-243$. [France]

Niggemann M. Jetzkowitz J. Brunzel S.Wichmann M.C.Bialozyt R. 2009. Distribution patterns of plants explained by human movement behavior. Ecol Model 220: 1339-1346.

Pascal JP. 2003. Notions sur les structures et dynamiques des forêts tropicales humides. Rev. For. Fr. LV.

Pastorella F, Paletto A. 2013. Stand structure indices as tools to support forest management: an application in Trentino forests (Italy). J For Sci 59 (4): 159-168.

Philip SM. 2002. Measuring Trees and Forests. 2nd ed. Londres, Royaume-Uni \& CABI, UK.

Pielou EC. 1969. An introduction to Mathematical Ecology. WitleyInterscience, New York.

Rached-Kanouni M, Belhiouani H, Hadef A. 2015. Hardwood forest inventory of Dra-Naga Arboretum (Djebel El Ouahch, Constantine, Algeria). Intl J Adv Agric Environ 2 (2): 91-93.

Ramalanjoana M. 2013. Etude de la régénération de la sénescence de Tamarindus indica et ses impacts et implications écologiques dans la réserve de Bezà Mahafaly. [Mémoire d'ingénieur] en sciences agonomique. Université d'Antananarovi, Madagascar. [France]

Rebbah AC. 2019. Inventaire des oiseaux forestièrs de Djebal Sidi Reghis (Oum El Bouaghi). [Thèse doctorat], université larbi Ben M'hidi Oum El Bouaghi, Algéria. [France]

Routledge R D. 1979. Diversity indices: Which ones are admissible? J Theor Biol 76 (4): 503-515.

Simboura N, Zenetos A. 2002. Benthic indicators to use in ecological quality classification of Mediterranean soft bottom marine ecosystems, including a new biotic index. Mediterranean Mar Sci 3 (2): 77-111

Schlaepfer R. 2002. Analyse de la dynamique du paysage. Fiche d'enseignement 4.2, Ecole Polytechnique fédérale de Lausanne, Suisse. [France]

Svensson J S, Jeglum J. K.2001. Structure and dynamics of an undisturbed old-growth Norway spruce forest on the rising Bothnian coastline. For Ecol Manag 151 (1-3): 67-79.

Tessi DRY. 2012.Caractéristiques structurales et écologiques des populations de Antiaris toxicaria (Pers) Lesh et Ceiba pentandra (L.) Gaertn dans les forêts reliques du Sud-Bénin. Int J Biol Chimical Sci. ISSN: 1991-8631.

Thiombiano A, Glele Kakaï R, Bayen P, Boussim JI, Mahamane A. 2016. Méthodes et dispositifs d'inventaires forestiers en Afrique de l'ouest : état des lieux et propositions pour une harmonisation. Annales des Sciences Agronomiques 20 - spécial Projet Undesert-UE: 15-31. [France]

Webster PJ. Holland GJ, Curry JA. Chang HR. 2005. Changes in tropical cyclone number, duration, and intensity in a warming environment. Science 309: 1844-1846.

Whitmore TC. 1990. An Introduction to Tropical Rain Forest. Clarendo Press, Oxford 